\title{
Large Wood Volume and Longitudinal Distribution in Channel Segments Draining Catchments with Different Land Use, Chile
}

\author{
A. Iroumé1, L. Mao², H. Ulloa ${ }^{3}$, C. Ruz ${ }^{4}$, A. Andreoli5 \\ ${ }^{1}$ Faculty of Forest Sciences and Natural Resources, Universidad Austral de Chile, Valdivia, Chile \\ ${ }^{2}$ Department of Ecosystems and Environments, Pontificia Universidad Católica de Chile, Santiago, Chile \\ ${ }^{3}$ Faculty of Forest Sciences and Natural Resources, Universidad Austral de Chile, Graduate School, Valdivia, \\ Chile \\ ${ }^{4}$ Faculty of Engineering Sciences, School of Civil Engineering, Universidad Austral de Chile, Valdivia, Chile \\ ${ }^{5}$ Department of Forestry and Environmental Management, Universidad de Concepción, Concepción, Chile \\ Email: airoume@uach.cl
}

Received 1 April 2014; revised 15 April 2014; accepted 22 April 2014

Copyright (C) 2014 by authors and Scientific Research Publishing Inc.

This work is licensed under the Creative Commons Attribution International License (CC BY). http://creativecommons.org/licenses/by/4.0/

(c) (i) Open Access

\section{Abstract}

The storage, longitudinal distribution and recruitment processes of in-stream large wood (LW) were studied comparing channel segments draining four Chilean mountain catchments with different land use. The segments were divided into relatively uniform reaches of different lengths and surveyed for LW (piece dimensions, position in the channel, orientation to flow and aggregation) and stream morphology (slope and bank full channel width and depth) characterizations. LW volume stored in the Pichun, El Toro and Vuelta de Zorra study channels are within the range informed in international researches from streams draining catchments with similar forest covers. However, the $1057 \mathrm{~m}^{3} / \mathrm{ha}$ of LW stored in Tres Arroyos is extremely high and in the same order of magnitude than the reports from old-growth forests in the Pacific Northwest of USA. The size of the area that can potentially provide wood to streams depends on the wood supply mechanisms within any catchment, and the LW stored in the study segments increases as the size of this area increases. This study aims to contribute to the knowledge on the effects of LW in mountain channels, gathering new information and expanding investigations developed in Chile since 2008. This research was carried out within the framework of Project FONDECYT 11106209.

\section{Keywords}

Large Wood, Wood Storage, LW Longitudinal Distribution, Mountain Catchments

How to cite this paper: Iroumé, A., Mao, L., Ulloa, H., Ruz, C. and Andreoli, A. (2014) Large Wood Volume and Longitudinal Distribution in Channel Segments Draining Catchments with Different Land Use, Chile. Open Journal of Modern Hydrology, 4, 57-66. http://dx.doi.org/10.4236/ojmh.2014.42005 


\section{Introduction}

Large wood (LW, wood pieces with diameter $\geq 0.1 \mathrm{~m}$ and length $\geq 1 \mathrm{~m}$ ) is an important component of fluvial systems. When deposited within the channel bed and in floodplains and islands wood pieces exert significant morphologic and ecologic influences in riverine ecosystems [1]. The amount and characteristics of LW, and consequently their eco-morphologic role in rivers, depend on the location, magnitude, and timing of logs recruitment, and on the log transport through reaches. Wood budgets at a reach scale depend on the balance between wood supply from the fall of trees from the riverine vegetation, the input of wood pieces recruited from landslides and tributary channels, in-situ decay and transport during floods [2]. Wood budgets and dominating wood recruitment processes are strongly dependent on the history of land use within the catchments, although the occurrence of episodic disturbances such as wildfires, pest outbursts or volcanic eruptions can dramatically change the conditions and relative contributions of the areas that supply wood into the streams [3].

Longitudinal transfer of LW along a stream is influenced by the characteristics of the wood pieces (storage and diameter, length, and wood density), the morphology of the channel (dimensions of bankfull channel, slope, bed forms and roughness) and flow conditions [4] and [5]. The amount and longitudinal distribution of wood have been studied in many rivers of the world, and findings demonstrate that wood distribution depends on land use at the basin scale, size of the basin, fire disturbance, flow regime, riparian vegetation, and morphology of the river [4]-[6].

LW has been investigated in Chile since 2005 [7] with further developments as reported by [8]-[12]. This study adds to existing information on LW volume and wood piece characteristics in Chilean streams, as four stream channels draining mountain catchments with different histories of land uses have been surveyed for this scope. Besides, LW longitudinal distribution patterns along each channel were analyzed as well as the relation between stored wood volumes and the dimensions of the catchments, the supply mechanisms and the surface of the areas that can potentially supply wood to streams. Existing and new information is gathered to expand a research that has been developed since 2008 in four catchments located both in the Coastal and Andes mountain ranges, southern Chile.

\section{Study Sites}

The study was carried out in four catchments located in the Coastal and Andes mountain ranges of southern Chile, namely Pichún, El Toro, Tres Arroyos and Vuelta de Zorra (Figure 1).

Pichún (37 $\left.30^{\prime} 12^{\prime \prime S} ; 2^{\circ} 45^{\prime} 54^{\prime \prime} \mathrm{W}\right)$ is located in the Coastal Mountain range. The $84 \%$ of the 431 ha catchment

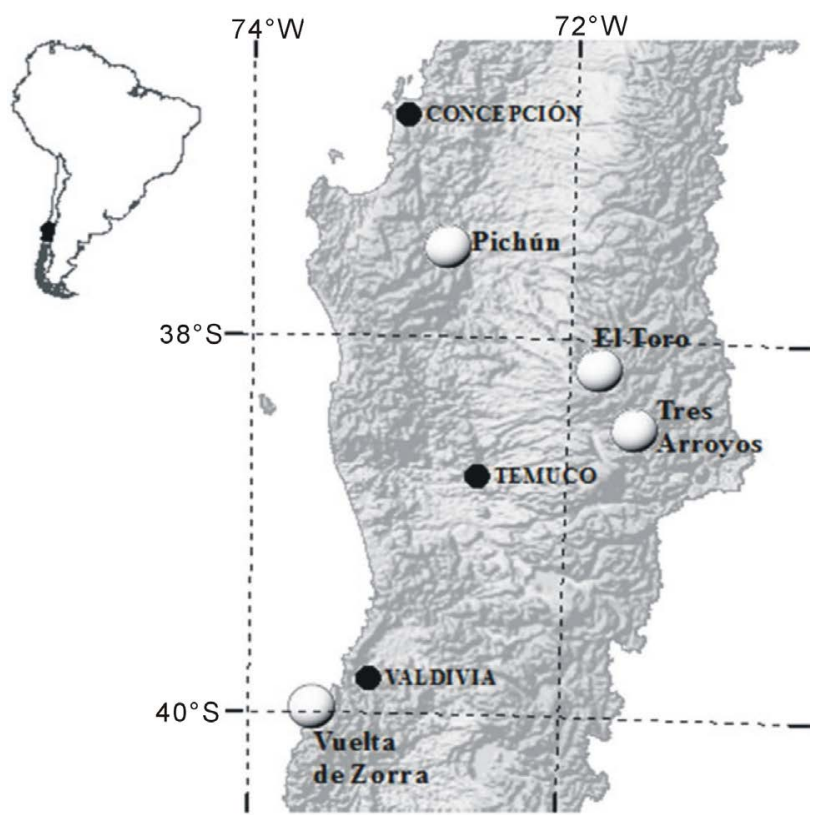

Figure 1. In white circles the location of the study sites. In black circles the position of main cities. 
area is covered by Eucalyptus globulus plantations established during 2005-2008, and the 16\% are forest roads and riparian vegetation. The original native forests of the area were almost completely clear cut at the end of the 1800's and transformed into crop lands, and since mid-1950's the area was re-afforested with Pinus radiata plantations. These plantations were managed with rotations of $\sim 25$ years and after two consecutive pine rotations this species was replaced by Eucalyptus spp. The dominant soil type is a clayey to loamy Luvisol and homogeneous schist forms the geological basement and parental material which is overlaid by a loamy-sandy saprolite. The stream has a pluvial regime associated to mean annual rainfalls of $1150 \mathrm{~mm}$ concentrated between April and September. Large wood is supplied into the main channel only from the riparian area (some native but mainly $P$. radiata trees from the previous rotations) through natural mortality, windthrowing or bank erosions. Further details on this site can be found in [10] and [11].

El Toro $\left(38^{\circ} 09^{\prime} 11^{\prime \prime S} ; 71^{\circ} 48^{\prime} 12^{\prime \prime} \mathrm{W}\right)$ is located on the Andes range. The entire catchment area is part of the Malleco Forest Reserve managed and protected by the National Forest Service (CONAF). The 1750 ha catchment area was originally covered by a Coigüe-Raulí-Tepa (Nothofagus dombeyi, N. alpina and Laureliopsis philippiana) evergreen forest type. During the 2001-2002 fire season, catastrophic fires burned $\sim 20000$ ha of temperate forests in the Andean areas of the Araucania region of Chile, and near the $98 \%$ of the El Toro forest cover was severely affected. The vegetation in these burnt sites is regenerating naturally. Soils derive from volcanic ashes, and the geology is characterized mainly by basaltic and andesite rocks but also with the presence of granitic rocks. The stream has a mainly pluvial regime dominated by annual rainfalls exceeding $2500-3000 \mathrm{~mm}$ at lower elevations and 4000 - $5000 \mathrm{~mm}$ with snowfall participation at higher altitudes. In-stream large wood is supplied by the fall of trees associated to natural mortality, windthrowing, or bank erosions, and the last years by the falling of burnt dead trees. Further information on this study site is provided in [8].

Tres Arroyos ( $38^{\circ} 27^{\prime} 57^{\prime \prime S}$; $71^{\circ} 33^{\prime} 44^{\prime \prime} \mathrm{W}$ ) is located on the foothills of the Andes range. The $64 \%$ of the 907 ha catchment area is covered with old grown native forests belonging to the Araucaria (Araucaria araucana) and Roble-Raulí-Coigüe ( $N$. obliqua, $N$. alpina and $N$. dombeyi) forest types, the 6.5 are exotic conifer plantations established in the 1970's, $23 \%$ are herbs and shrubs near the tree line and 6.5\% are volcanic ashes. Soils are sandy-rich and the geology of the area is characterized by a Miocenic formation with pyroclastic rocks such as andesite breccias, tuffs and ignimbrites, lavas and sedimentary layers. The stream has a mainly pluvial regime dominated by annual rainfalls exceeding $2500 \mathrm{~mm}$, with snowfall occasionally occurring. Forests of the area were partially eliminated during the 1930-1940 by big fires initiated to open land for grasslands but the upper 600 ha of the catchment was not affected by these fires. The elimination of the forest cover, the steepness of the terrains and the climate characteristics triggered massive landslides and debris flows which forced CONAF to initiate in early 1970's the re-afforestation with exotic conifers. The catchment area is part of the Malalcahuello-Nalcas Forest Reserve managed and protected by CONAF. In-stream large wood is supplied by the fall of trees associated to natural mortality, windthrowing, diseases or bank erosions, especially in the upper part of the study segments where the main stream flows through old native forests having massive $N$. dombeyi trees. However, [7] report peaks of LW in the main channel associated with steep debris flow tributaries and landslides. More information on this study site is provided in [7] and [8].

The fourth study catchment is Vuelta de Zorra (39 $58^{\prime} 12^{\prime \prime S}$; $73^{\circ} 34^{\prime} 13^{\prime \prime}$ ), which is located in the Coastal mountain range. The $75 \%$ of the 587 ha study catchment area is covered by a 150 - 200 years old second growth evergreen native rainforest about, $24 \%$ by $E$. nitens plantations and the remaining by natural regeneration of native shrubs. Soils are clayed-rich on the eastern side of the main channel and sandy-rich on the west, and the geology of the Coastal mountain range has a basement of Paleozoic metamorphic rocks and minor Cretaceous granitoids with one of these appearing in the study area. The stream has pluvial regime dominated by annual rainfalls exceeding $2300 \mathrm{~mm}$. Forests of the area were affected by the wood industry developed since the 1800's associated to the exploitation of Fitzroya cupressoides and other native tree species, and then by a project that began in 2000 intended to replace native forests by Eucalyptus spp. plantations. This project did not last and since mid-2003 the catchment is part of The Nature Conservancy owned Valdivian Coastal Reserve. In-stream large wood to the main channel is supplied only by the fall of trees associated to natural mortality, windthrowing, diseases or bank erosions. Additional information of this study site can be found in [9]-[11].

\section{Methods}

\subsection{Characterization of the Channel Segments}

Between November 2008 and March 2009, several channel reaches of the Vuelta de Zorra, Tres Arroyos, El 
Toro and Pichun third order stream segments were surveyed for large wood and channel morphological characterization. Every reach was defined by uniformity of slope, channel width or LW abundance, as in [9].

Overall, the length of the study segments were $1004 \mathrm{~m}$ (12 reaches), $2188 \mathrm{~m}$ (17 reaches), $2070 \mathrm{~m}$ (22 reaches) and $1557 \mathrm{~m}$ (16 reaches), and for the Pichún, El Toro, Tres Arroyos and Vuelta de Zorra streams, respectively. The study segments represented the 31, 28, 39 and 45\% of the total length of the Pichún, El Toro, Tres Arroyos and Vuelta de Zorra main streams.

A laser distance meter with an inclinometer was used to calculate reach length and channel slope, and reach mean channel bank full width $\left(\mathrm{W}_{\mathrm{bf}}\right)$ and depth $\left(\mathrm{H}_{\mathrm{bf}}\right)$ were calculated averaging measurements from cross-sections less than 15-m apart. Unit stream power for bank full conditions was calculated by means of a simplified version of the traditional equation as suggested by [13], using:

$$
\omega=\frac{\gamma\left(\sqrt{g H_{b f}}\right)\left(H_{b f} W_{b f}\right) S_{c}}{W_{b f}}
$$

where $\omega$ is unit stream power $\left(\mathrm{W} / \mathrm{m}^{2}\right), \gamma$ the specific weight of water $\left(\mathrm{N} / \mathrm{m}^{3}\right)$, g the acceleration due to gravity in $\left(\mathrm{m} / \mathrm{s}^{2}\right), \mathrm{H}_{\text {bf }}$ and $\mathrm{W}_{\text {bf }}$ the mean reach bank full depth and width $(\mathrm{m})$, and $\mathrm{S}_{\mathrm{c}}$ the mean reach channel slope $(\mathrm{m} / \mathrm{m})$.

All individual or jam forming wood pieces with diameter $\geq 0.1 \mathrm{~m}$ and length $\geq 1 \mathrm{~m}$ located within the bank full channel were measured for length and mid-diameter. The volume of each wood element was calculated from its mid-diameter and length assuming a solid cylindrical shape, and during the field campaigns the geometric dimensions of jams (length, width and height) were measured and the wood pieces were classified according to its type, position in the channel, source, orientation to flow and aggregation (single elements or jam forming logs), following [7] and [9].

\subsection{Surface of Riparian Areas That Can Provide Large Wood to Streams}

The surface of the riparian areas that can potentially provide wood to streams was calculated considering the large wood recruitment processes within each river segment.

At the Vuelta de Zorra, El Toro and Pichun channel segments the main recruitment process is associated to the fall of trees into the stream by natural causes (toppling because of mortality or windthrowing, deseases, or bank cuttings). In the Vuelta de Zorra and El Toro channels, the recruitment area is limited at both sides of the channel by the height of the tallest trees ( $35 \mathrm{~m}$ for Vuelta de Zorra and $37 \mathrm{for}$ El Toro). In Pichun, this area is restricted by the width of the riparian area $(25 \mathrm{~m})$, considering that the rest of this catchment is covered by plantation forests that are clear cut regularly at the end of every rotation. In Tres Arroyos, adding to the fall of trees from the riparian area limited at both sides of the channel by the height of the tallest trees $(37 \mathrm{~m})$ is the LW recruitment process associated to the transport of wood into the main channel by very active torrential tributaries. In this case, the surface of the recruitment areas of these streams (limit of $37 \mathrm{~m}$ at both sides of the channel) is totaled with the one of the main channel. In all cases, the area that can potentially provide wood to streams is expressed in hectares per $100 \mathrm{~m}$ of the study segment.

\subsection{Statistical Analyses}

Regressions were used to examine longitudinal distribution patterns of LW along the channels, using reach mean channel bank full width and depth, and slope and unit stream power as independent variables and LW reach mean diameter, length, volume $\left(\mathrm{m}^{3}\right.$ per hectare of bank full channel) and piece abundance (number of pieces per hectare of bank full channel) as dependent variables. The potential relationships between total segment LW volume ( $\mathrm{m}^{3}$ per hectare of bank full channel) with catchment size (ha) and the surface (ha/ $\left.100 \mathrm{~m}\right)$ that can potentially provide wood to streams were studied using linear regressions. The SAS ${ }^{\circledR}$ package was used and regressions were considered statistically significant if $P \leq 0.05$.

\section{Results and Discussion}

\subsection{Reach Channel Characteristics}

The main characteristics of each stream reach, a reach channel length, slope, bankfull depth $\left(\mathrm{H}_{\mathrm{bf}}\right)$ and width $\left(\mathrm{W}_{\mathrm{bf}}\right)$ and unit stream power are provided in Table 1. Tres Arroyos and Pichún are the steeper $(0.098$ and $0.097 \mathrm{~m} / \mathrm{m}$ 
Table 1. Reach morphologic characteristics in the study segments.

\begin{tabular}{|c|c|c|c|c|c|c|c|c|c|c|c|c|c|c|c|c|c|c|c|c|}
\hline \multirow{2}{*}{$\begin{array}{c}\text { Reach } \\
\mathrm{N}^{\circ}\end{array}$} & \multicolumn{5}{|c|}{ Pichun } & \multicolumn{5}{|c|}{ El Toro } & \multicolumn{5}{|c|}{ Tres Arroyos } & \multicolumn{5}{|c|}{ Vuelta de Zorra } \\
\hline & $\mathrm{L}$ & $\mathrm{S}_{\mathrm{c}}$ & $\mathrm{H}_{\mathrm{bf}}$ & $\mathrm{W}_{\mathrm{bf}}$ & $\omega$ & $\mathrm{L}$ & $\mathrm{S}_{\mathrm{c}}$ & $\mathrm{H}_{\mathrm{bf}}$ & $\mathrm{W}_{\mathrm{bf}}$ & $\omega$ & $\mathrm{L}$ & $\mathrm{S}_{\mathrm{c}}$ & $\mathrm{H}_{\mathrm{bf}}$ & $\mathrm{W}_{\mathrm{bf}}$ & $\omega$ & $\mathrm{L}$ & $\mathrm{S}_{\mathrm{c}}$ & $\mathrm{H}_{\mathrm{bf}}$ & $\mathrm{W}_{\mathrm{bf}}$ & $\omega$ \\
\hline & $\mathrm{m}$ & $\mathrm{m} / \mathrm{m}$ & $\mathrm{m}$ & $\mathrm{m}$ & $\mathrm{W} / \mathrm{m}^{2}$ & $\mathrm{~m}$ & $\mathrm{~m} / \mathrm{m}$ & $\mathrm{m}$ & $\mathrm{m}$ & $\mathrm{W} / \mathrm{m}^{2}$ & $\mathrm{~m}$ & $\mathrm{~m} / \mathrm{m}$ & $\mathrm{m}$ & $\mathrm{m}$ & $\mathrm{W} / \mathrm{m}^{2}$ & $\mathrm{~m}$ & $\mathrm{~m} / \mathrm{m}$ & $\mathrm{m}$ & $\mathrm{m}$ & $\mathrm{W} / \mathrm{m}^{2}$ \\
\hline 1 & 135 & 0.047 & 1.00 & 5.4 & 1444 & 187 & 0.015 & 1.25 & 17.0 & 660 & 97 & 0.081 & 1.08 & 9.8 & 786 & 94 & 0.017 & 1.25 & 8.8 & 713 \\
\hline 2 & 90 & 0.052 & 0.98 & 5.2 & 1538 & 146 & 0.024 & 1.78 & 12.2 & 723 & 30 & .145 & 1.50 & 8.6 & 160 & 38 & .009 & 1.36 & 9.6 & 447 \\
\hline 3 & 59 & 0.051 & 0.95 & 4.0 & 451 & 104 & 0.043 & 1.65 & 11.9 & 2822 & 121 & 0.083 & 1.15 & 10.6 & 3136 & 84 & .020 & 1.19 & 10.0 & 812 \\
\hline 4 & 76 & 0.066 & 0.80 & 4.4 & 1451 & 146 & 0.024 & 1.40 & 13.9 & 1206 & 109 & 0.079 & 1.10 & 9.9 & 2790 & 69 & 0.020 & 1.04 & 12.6 & 657 \\
\hline 5 & 62 & 0.065 & 0.66 & 5.7 & 1071 & 101 & 0.033 & 1.75 & 15.3 & 2351 & 115 & 0.076 & 1.10 & 9.8 & 2704 & 58 & 0.019 & 0.96 & 2.1 & 563 \\
\hline 6 & 100 & 0.042 & 0.74 & 5.5 & 813 & 62 & 0.027 & 1.60 & 13.7 & 1670 & 100 & 0.086 & 1.15 & 9.2 & 3248 & 143 & 0.037 & 1.09 & 11.2 & 1284 \\
\hline 7 & 108 & 0.049 & 0.82 & 4.6 & 1110 & 109 & 0.037 & 1.60 & 13.5 & 2316 & 119 & 0.063 & 1.08 & 9.4 & 2150 & 111 & 0.005 & 1.19 & 11.1 & 193 \\
\hline 8 & 35 & 0.128 & 0.80 & 5.0 & 2814 & 80 & 0.083 & 1.90 & 8.0 & 6682 & 112 & 0.073 & 0.90 & 12.1 & 1906 & 85 & 0.043 & 1.15 & 12.4 & 1639 \\
\hline 9 & 84 & 0.068 & 0.84 & 4.6 & 1599 & 155 & 0.040 & 1.50 & 13.6 & 2242 & 58 & 0.084 & 1.00 & 11.5 & 2581 & 104 & 0.036 & 1.04 & 13.4 & 1166 \\
\hline 10 & 99 & 0.103 & 0.86 & 4.2 & 2539 & 212 & 0.041 & 1.45 & 12.0 & 2225 & 114 & 0.121 & 1.05 & 10.5 & 3993 & 138 & 0.043 & 1.06 & 11.5 & 1424 \\
\hline 11 & 129 & 0.249 & 0.80 & 4.4 & 5440 & 82 & 0.098 & 2.00 & 9.1 & 8487 & 88 & 0.048 & 0.85 & 15.0 & 1161 & 127 & 0.035 & 0.87 & 10.9 & 881 \\
\hline 12 & 27 & 0.243 & 0.80 & 4.4 & 5309 & 142 & 0.065 & 1.85 & 12.3 & 5021 & 77 & 0.122 & 0.90 & 12.0 & 3190 & 143 & 0.062 & 0.80 & 9.5 & 1365 \\
\hline 13 & & & & & & 101 & 0.110 & 2.49 & 8.0 & 13280 & 72 & 0.069 & 0.85 & 9.8 & 1658 & 123 & 0.054 & 0.93 & 8.7 & 1495 \\
\hline 14 & & & & & & 157 & 0.065 & 1 & 11.2 & 42 & 32 & 83 & 0.98 & 8. & 2444 & 86 & 80 & 0 & .2 & 1626 \\
\hline 15 & & & & & & 144 & 0.063 & 1.36 & 14.0 & 30 & 87 & 97 & 0.80 & & 30 & 102 & 0.091 & 0. & 9.3 & 1640 \\
\hline 16 & & & & & & 115 & 0.058 & 1.52 & 16.2 & 3334 & 48 & 0.180 & 0.74 & 10.5 & 3526 & 52 & 0.073 & 0.84 & 9.8 & 1723 \\
\hline 17 & & & & & & 145 & 0.072 & 1.45 & 17.5 & 3873 & 132 & 0.081 & 0.91 & 8.3 & 2173 & & & & & \\
\hline 18 & & & & & & & & & & & 83 & 0.084 & 1.78 & 9.5 & 6157 & & & & & \\
\hline 19 & & & & & & & & & & & 84 & 0.114 & 1.40 & 13.2 & 5802 & & & & & \\
\hline 20 & & & & & & & & & & & 96 & 0.171 & 1.20 & 7.8 & 6912 & & & & & \\
\hline 21 & & & & & & & & & & & 111 & 0.065 & 1.30 & 6.3 & 2955 & & & & & \\
\hline 22 & & & & & & & & & & & 125 & 0.144 & 1.30 & 6.4 & 6551 & & & & & \\
\hline Total & 1004 & & & & & 2188 & & & & & 2070 & & & & & 1557 & & & & \\
\hline Mean & & 0.097 & 0.84 & 4.8 & 2215 & & 0.053 & 1.66 & 12.9 & 3836 & & 0.098 & 1.10 & 9.9 & 3551 & & 0.04 & 1.00 & 10.6 & 1102 \\
\hline
\end{tabular}

respectively) and Vuelta de Zorra and El Toro the flatter (0.04 and $0.053 \mathrm{~m} / \mathrm{m}$ respectively) segments. At the reach level, Tres Arroyos and Pichún also feature the steeper reaches (up to $0.249 \mathrm{~m} / \mathrm{m}$ ) whereas in Vuelta de Zorra and El Toro reach slopes are generally lower than $0.1 \mathrm{~m} / \mathrm{m}$. Reach and segment bank full depth $\left(\mathrm{H}_{\mathrm{bf}}\right)$ are of the same order of magnitude for Vuelta de Zorra, Tres Arroyos and Pichún but much higher at El Toro. Reach and segment bankfull width $\left(\mathrm{W}_{\mathrm{bf}}\right)$ are similar for Vuelta de Zorra and Tres Arroyos, while Pichún is the narrowest (4.8 $\mathrm{m}$ of mean segment bankfull width) and El Toro the widest (12.9 $\mathrm{m}$ of mean segment bankfull width) among the study channels.

Mean segment unit stream ( $\omega$ in Table 1) is relatively similar for El Toro and Tres Arroyos (3836 and 3551 $\mathrm{W} / \mathrm{m}^{2}$ respectively), but lower in Pichún $\left(2215 \mathrm{~W} / \mathrm{m}^{2}\right)$ and even much lower in Vuelta de Zorra $\left(1102 \mathrm{~W} / \mathrm{m}^{2}\right)$.

\subsection{Abundance and Characteristics of In-Stream Large Wood}

A total of 113, 776, 2636 and 487 large wood pieces were found in the Pichún, El Toro, Tres Arroyos and Vuelta de Zorra study segments. Considering the channel bankfull area as reference, the abundance of wood pieces in number of wood pieces per bankfull area $\left(\mathrm{n}^{\circ} / \mathrm{ha}\right)$ is relatively similar for Pichún, El Toro and Vuelta de Zorra (235, 269 and $295 \mathrm{n}$ /ha, respectively), but much higher in Tres Arroyos with a total of $1310 \mathrm{n}^{\circ} / \mathrm{ha}$. Reach large wood abundance is highly variable (Figure 2). In Pichun reach large wood abundance varies from 0 to $440 \mathrm{n} / \mathrm{ha}$, between 82 and $741 \mathrm{n}^{\circ}$ /ha at El Toro, from 444 and $2702 \mathrm{n}^{\circ} / \mathrm{ha}$ in Tres Arroyos and between 82 and $914 \mathrm{n} / \mathrm{ha}$ in the Vuelta de Zorra study channel. As reported by [13] studying 13 channels in the Italian Alps, large wood abundance can be also much variable (from 200 to $2500 \mathrm{n}^{\circ} / \mathrm{ha}$ among reaches), but in this case they measured wood pieces with diameters $\geq 5 \mathrm{~cm}$ and lengths $\geq 50 \mathrm{~cm}$. 

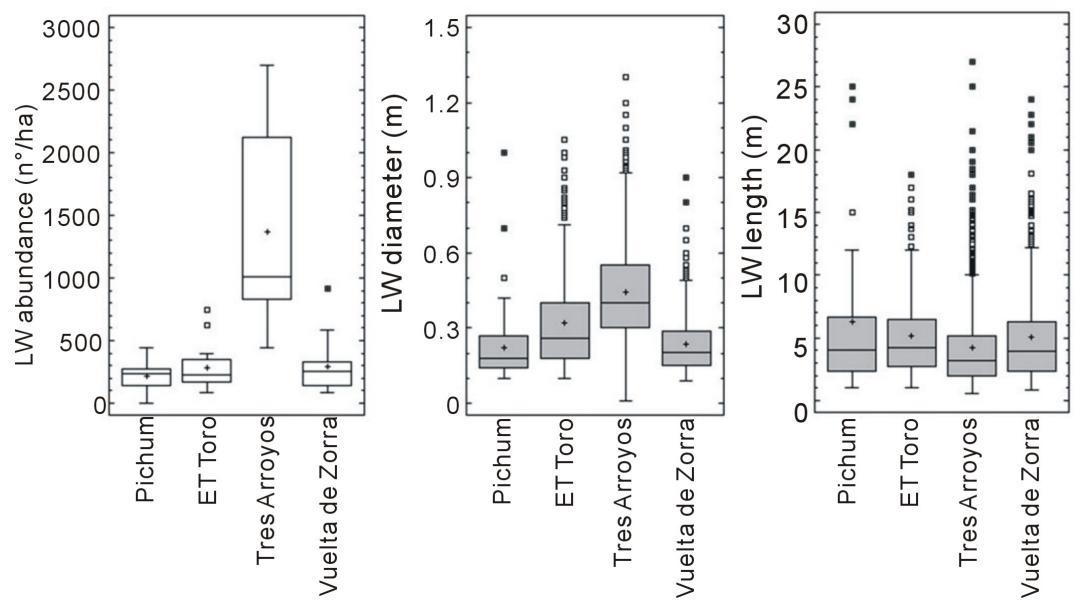

Figure 2. Box plots of reach LW abundance (left), diameter (center) and length (right). The cross and line within each box indicate the mean and median values, box ends are $25^{\text {th }}$ and $75^{\text {th }}$ percentiles, whiskers are the $10^{\text {th }}$ and $90^{\text {th }}$ percentiles, and dots are outliers.

Reach scale dimensions (mid-diameter and length) of these wood pieces are summarized in Figure 2. Mean (cross within the box) and median (horizontal line within the box) diameters are much similar for Pichun and Vuelta de Zorra, higher for El Toro and still much higher for Tres Arroyos. El Toro and Tres Arroyos store the larger wood pieces with diameters up to $1.3 \mathrm{~m}$. Mean and median wood piece lengths are similar among the different segments, although some 28 m-long pieces were found lying on the Tres Arroyos channel.

The ratio of mean piece diameter to mean segment bankfull depth is approximately $0.23,0.18,0.36$ and 0.2 for Pichún, El Toro, Tres Arroyos and Vuelta de Zorra, while the ratio of mean piece length to mean segment bankfull width is $0.8,0.3,0.4$ and 0.4 for the same segments. According to [14]-[16], pieces tend to be stable when piece length is greater than bank full width in smaller rivers, or when piece diameter is higher than bank full depth. According to the values of these ratios for the four study segments, LW mobility might be highly possible even under normal peak flows.

Almost all the wood pieces in El Toro and Tres Arroyos (100 and 99.7\% respectively) were logs, and this percentage is reduced to $91 \%$ for Pichun and Vuelta de Zorra. In these two last segments the rest of the wood pieces are rootwads, boles with rootwads, full trees and branches.

At the El Toro, Tres Arroyos and Vuelta de Zorra the majority of the LW (94\%, 84\% and 75\% respectively) were found within the channel or at the bank full level (Figure 3). Wood pieces on the stream margins (lying on the floodplains but at least with part of the element in contact with the bank full channel) or spanning the channel are important in Pichun and Vuelta de Zorra, and log-steps were found in all the study segments. One log-step was found both at the Pichún and El Toro segments and 78 and 14 at the Tres Arroyos and Vuelta de Zorra, respectively. The majority of the LW pieces in El Toro, Tres Arroyos and Vuelta de Zorra segments were classified as having been transported from upstream locations (see also Figure 3). This trend is different in Pichun, were most of the in-stream wood was classified as residues and recruited as trees falling from the margins by natural causes or bank erosions. Residues from the forest activities are important in the Pichun and Vuelta de Zorra segments reflecting the conditions of land uses of their catchments.

The $41 \%$ of the wood pieces within the Pichun and Vuelta de Zorra segments were found lying parallel to the stream flow. The majority of the LW was found at El Toro oblique (42\%) and in Tres Arroyos orthogonal (36\%) to the flow.The orientation of the logs respect to the stream flow is a consequence of the transport dynamics of the wood pieces, and [17] and [18] inform that wood pieces oriented at $45^{\circ}$ and $90^{\circ}$ to the flow are more mobile while [19] indicate that fluvially deposited wood pieces tend to be oriented parallel to flow.

Most of the LW was found as single elements and the rest lying in contact with at least one other wood piece, but the proportion is different among segments. Pichun features only a few accumulations, and in average one logjam each $251 \mathrm{~m}$, while the mean distance between logjams is very similar for El Toro and Vuelta de Zorra (58 and $63 \mathrm{~m}$, respectively). At the Tres Arroyos, one logjam occurs in average each $15 \mathrm{~m}$ and this short distance should be associated to the very high volume of LW stored in this channel and the dimensions of the wood 
(a)

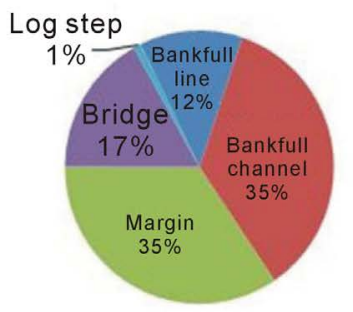

(a)

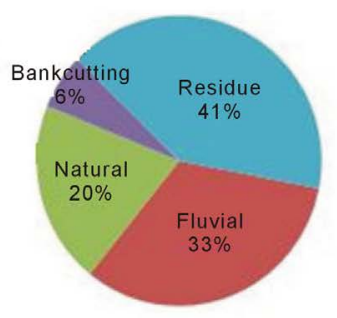

(b)

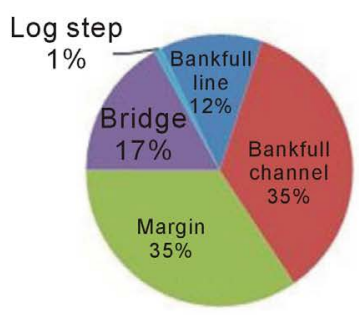

(b)

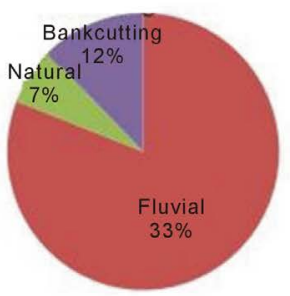

(c)

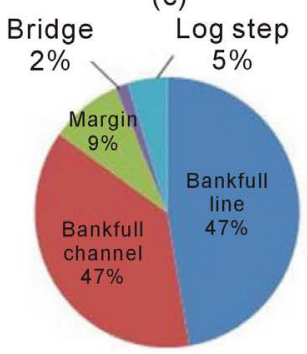

(c)

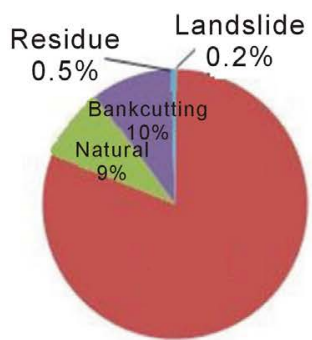

(d)

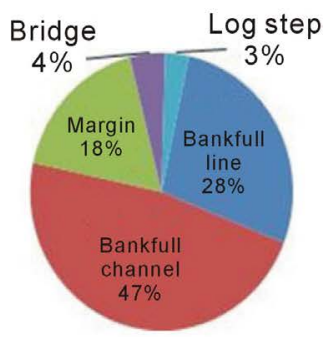

(d)

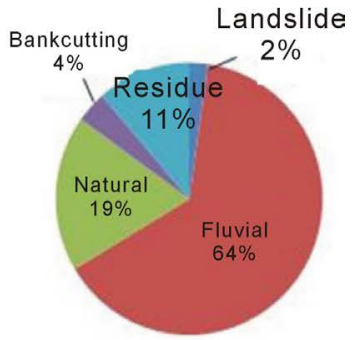

Figure 3. Position in the channel (above) and origin (below) of large wood pieces.a) Pichun; b) El Toro; c) Tres Arroyos; d) Vuelta de Zorra.

elements recruited from the margins that act as key pieces contributing to create stable logjams. Considering logjams and logsteps, in average each 201, 61, 10 and $38 \mathrm{~m}$ large wood structures are influencing the morphology of the Pichun, El Toro, Tres Arroyos and Vuelta de Zorra channels.

\subsection{Reach Volume and Longitudinal Distribution of In-Stream Large Wood}

Considering the channel bank full area as reference, LW volume is 56, 202, 1057 and $109 \mathrm{~m}^{3} /$ ha for Pichun, El Toro, Tres Arroyos and Vuelta de Zorra, respectively (Table 2). The volume stored in Pichun is within the range of mean values from 4 to $127 \mathrm{~m}^{3} /$ ha reported by [3] [20] and [21] in streams draining pine forested catchments in New Zealand, Spain, Russia and the NW USA. LW volume at El Toro and Vuelta de Zorra (202 and 109 $\mathrm{m}^{3} / \mathrm{ha}$ ) can be compared with the range from 100 and $200 \mathrm{~m}^{3} /$ ha informed by [22] from channels bordered by broadleaved mature forests. The $1057 \mathrm{~m}^{3} /$ ha of LW stored in Tres Arroyos is extremely high. For this channel [7] reported $\sim 710 \mathrm{~m}^{3} /$ ha of LW but their data was obtained from a shorter segment and using a sample of wood pieces to calculate volume. The value reported in this research is among the highest reported in the international literature and similar to the reports from old-growth forests in the Pacific Northwest of USA where according to [22] a wood storage up to $1000 \mathrm{~m}^{3} / \mathrm{h}$ a can be reached.

LW volume in the different segments is representative of the current and historical land uses within the catchments. The El Toro and Vuelta de Zorra catchments are covered with similar forest types, but the higher LW volume found in the channel of the former might be indicating an increase of wood supply associated to the fall of fire-killed trees during the 2002 wildfire. The lower volume at Pichun can be reasonably due to the fact that the original forests were eliminated more than a century ago to create grass and crop lands and then managed since the 1950's under a scheme of successive forest plantation rotations, then the recruitment of large wood is limited to a narrow fringe of riparian vegetation composed mainly by small native trees and $P$. radiata stems left behind from the previous final harvest. LW in Tres Arroyos is extremely high; the upper study segment flows through very old native forests with massive $N$. dombeyi trees and downstream it receives peaks of LW from steep tributaries.

LW storage is extremely variable among reaches (see Table 2), which is consistent with other studies [13]. Reach LW volume varies between 0 and $130 \mathrm{~m}^{3} /$ ha in Pichún, from 42 to $502 \mathrm{~m}^{3} / \mathrm{ha}$ at El Toro, from 418 to $2300 \mathrm{~m}^{3} /$ ha in Tres Arroyos and finally between 3 and $380 \mathrm{~m}^{3} /$ ha at the Vuelta de Zorra channel.

Reach LW volume longitudinal distribution is only explained (statically significant, $P=0.02$ ) for the Vuelta de Zorra channel by differences of reach mean bankfull width, while reach LW abundance longitudinal distribu- 
Table 2. LW volume stored in the different reaches and segments.

\begin{tabular}{|c|c|c|c|c|}
\hline Reach & Pichun & El Toro & Tres Arroyos & Vuelta de Zorra \\
\hline $\mathrm{N}^{\circ}$ & $\mathrm{m}^{3} / \mathrm{ha}$ & $\mathrm{m}^{3} / \mathrm{ha}$ & $\mathrm{m}^{3} / \mathrm{ha}$ & $\mathrm{m}^{3} / \mathrm{ha}$ \\
\hline 1 & 63.9 & 158.9 & 849.2 & 123.9 \\
\hline 2 & 51.4 & 308.5 & 793.4 & 3.3 \\
\hline 3 & 129.9 & 147.2 & 425.6 & 49.5 \\
\hline 4 & 0.0 & 223.3 & 762.9 & 135.4 \\
\hline 5 & 44.8 & 42.3 & 846.7 & 33.5 \\
\hline 6 & 108.9 & 134.0 & 1827.9 & 140.6 \\
\hline 7 & 9.0 & 60.0 & 417.5 & 224.3 \\
\hline 8 & 110.8 & 221.9 & 779.3 & 379.8 \\
\hline 9 & 33.3 & 112.1 & 1585.4 & 228.9 \\
\hline 10 & 21.3 & 169.7 & 1498.4 & 48.5 \\
\hline 11 & 57.9 & 47.8 & 712.8 & 34.2 \\
\hline 12 & 47.2 & 501.9 & 1720.2 & 18.9 \\
\hline 13 & & 251.6 & 1187.4 & 54.3 \\
\hline 14 & & 227.8 & 981.1 & 41.5 \\
\hline 15 & & 192.4 & 2300.4 & 52.3 \\
\hline 16 & & 437.8 & 1694.2 & 15.7 \\
\hline 17 & & 136.8 & 761.2 & \\
\hline 18 & & & 830.5 & \\
\hline 19 & & & 656.2 & \\
\hline 20 & & & 1874.2 & \\
\hline 21 & & & 501.9 & \\
\hline 22 & & & 1637.9 & \\
\hline Segment & 55.9 & 202.1 & 1057.3 & 109.2 \\
\hline
\end{tabular}

tion is not explained in any of the study segments by any of the independent variables used in the analyses (reach mean channel bankfull width and depth, and slope and unit stream power). Longitudinal distribution of reach mean LW diameter is explained only in the El Toro channel by differences in reach mean channel bankfull width and depth, and slope and unit stream power $(P \leq 0.05)$. Finally, longitudinal distribution of reach mean LW length is explained for Tres Arroyos and Vuelta de Zorra by differences of reach mean bankfull width ( $P \leq$ 0.05 ), and additionally for the Tres Arroyos channel by differences in reach mean unit stream power ( $P \leq$ 0.05).When examining the results of the regressions analyses between LW reach mean diameter, length, volume and piece abundance as dependent variables against reach mean channel bankfull width and depth, and slope and unit stream power, it is not straightforward to identify general longitudinal distribution patterns of LW along the channels. However, this agrees with the findings by [13] from their study in several channels in the Italian Alps.

\subsection{Relationships between Total Segment LW Volume with Catchment Size and the Area That Can Provide Wood to Streams}

The relationship between total segment LW storage (in $\mathrm{m}^{3} / \mathrm{ha}$ ) and catchment size (ha) is presented in Figure 4 . There is a weak trend showing an increase of LW storage with increasing catchment size. Previous studies have shown the same trend especially the conceptual model proposed by [23] which predict increasing LW storage for increasing drainage area in Japanese river systems, whereas others have not such as those by [13] and [24] from some Italian and North American streams presenting a negative correlation.

Segment large wood volume (in $\left.\mathrm{m}^{3} / 100 \mathrm{~m}\right)$ is significantly correlated $(P \leq 0.05)$ with the size of the area (ha/100m) that can potentially provide wood to streams (Figure 4). Large wood volume increases as the size of this area increases, and the dimension of this area is linked with the wood supply mechanisms within any catchment. Although the limitations of this linear model especially associated to the reduced number of study catchments, it could be used as a first approach to estimate large wood loads in Chilean forested environments. 

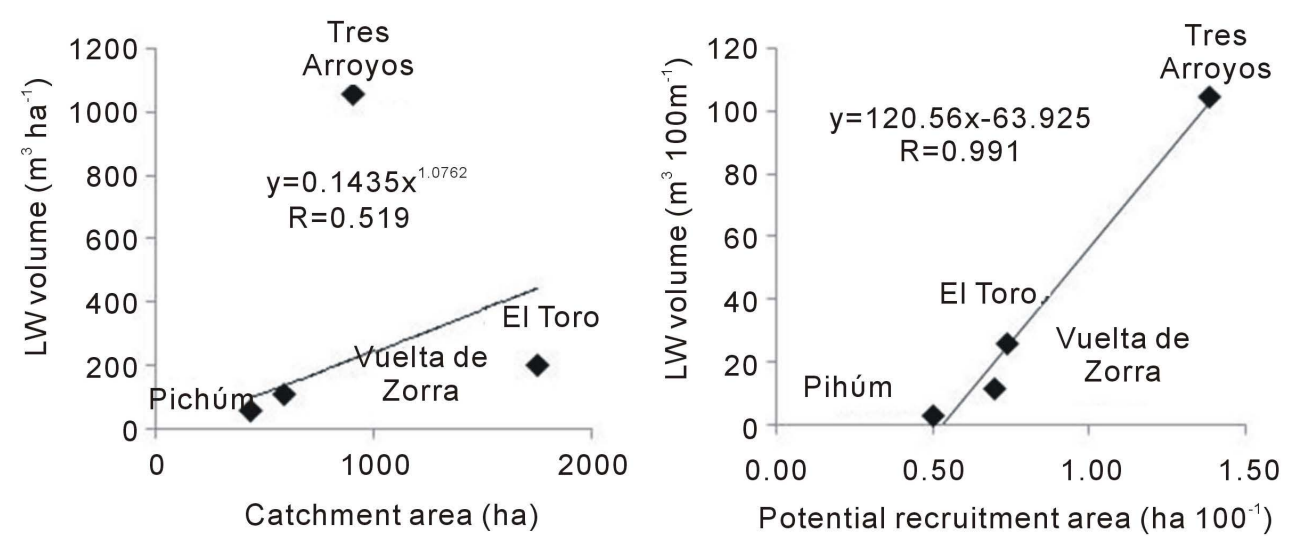

Figure 4. Relationships between total segment LW storage and catchment size (left) and between total segment LW storage and the surface of the area that can potentially provide wood to streams (right).

\section{Conclusions}

LW volume stored in the Pichun, El Toro and Vuelta de Zorra study segments fall within the range informed in other researches from streams draining catchments with similar forest covers, but the $1057 \mathrm{~m}^{3} / \mathrm{ha}$ of LW stored in Tres Arroyos is extremely high and similar than the reports from old-growth forests in the Pacific Northwest of USA. The size of the area that can potentially provide wood to streams depends on the wood supply mechanisms within any catchment which are very much associated to differences in characteristics and history of land use changes. In particular, landslides and debris-flows triggered by land use changes can increase the recruitment zone from the nearby riparian sector to the whole basin scale. The simple linear model correlating LW volume with the size of this area could be used as a first approach to estimate large wood loads in Chilean forested environments.

This study aims to contribute to the knowledge on the effects of LW in Chilean mountain channels. However, the abundance of LW in the study catchments, and the dimensions, origin, position in the channel and orientation to stream flow of the wood pieces suggest that large wood mobility might occur even under normal peak flows thus indicating the need to further study LW mobility.

\section{Acknowledgements}

This research was developed under Project FONDECYT 1110609. The authors recognize the support of Forestal Mininco S.A. (Pichún), Corporación Nacional Forestal (El Toro and Tres Arroyos) and The Nature Conservancy (Vuelta de Zorra).

\section{References}

[1] Abbe, T.B. and Montgomery, D.R. (2003) Patterns and Processes of Wood Debris Accumulation in the Queets River Basin, Washington. Geomorphology, 51, 81-107. http://dx.doi.org/10.1016/S0169-555X(02)00326-4

[2] Benda, L.E. and Sias, J.C. (2003) A Quantitative Framework for Evaluating the Mass Balance If In-Stream Organic Debris. Forest Ecology and Management, 172, 1-16. http://dx.doi.org/10.1016/S0378-1127(01)00576-X

[3] Baillie, B.R. and Davies, T.R. (2002) Influence of Large Woody Debris on Channel Morphology in Native Forest and Pine Plantation Streams in the Nelson Region. New Zealand Journal of Marine and Freshwater Resources, 36, 763774. http://dx.doi.org/10.1080/00288330.2002.9517129

[4] Jones, T.A. and Daniels, L.D. (2008) Dynamics of Large Woody Debris in Small Streams Disturbed by the 2001 Dogrib Fire in the Alberta Foothills. Forest Ecology and Management, 256, 1751-1759. http://dx.doi.org/10.1016/j.foreco.2008.02.048

[5] Wohl, E. and Goode, J.R. (2008) Wood Dynamics in Headwater Streams of the Colorado Rocky Mountains. Water Resources Research, 44, W09429. http://dx.doi.org/10.1029/2007WR006522

[6] Moulin, B., Schenk, E.R. and Hupp, C.R. (2011) Distribution and Characterization of In-Channel Large Wood in Relation to Geomorphic Patterns on a Low-Gradient River. Earth Surface Processes and Landforms, 36, 1137-1151. http://dx.doi.org/10.1002/esp.2135 
[7] Andreoli, A., Comiti, F. and Lenzi, M.A. (2007) Characteristics, Distribution and Geomorphic Role of Large Woody Debris in a Mountain Stream of the Chilean Andes. Earth Surface Processes and Landforms, 32, 1675-1692. http://dx.doi.org/10.1002/esp.1593

[8] Comiti, F., Andreoli, A., Lenzi, M.A. and Mao, L. (2008) Wood Storage in Three Mountain Streams of the Southern Andes and Its Hydro-Morphological Effects. Earth Surface Processes and Landforms, 33, 244-262. http://dx.doi.org/10.1002/esp.1541

[9] Iroumé, A., Andreoli, A., Comiti, F., Ulloa, H. and Huber, A. (2010) Large Wood Abundance, Distribution and Mobilization in a Third Order Coastal Mountain Range River System, Southern Chile. Forest Ecology and Management, 260, 480-490. http://dx.doi.org/10.1016/j.foreco.2010.05.004

[10] Iroumé, A., Ulloa, H.,Lenzi, M.A., Andreoli, A. and Gallo, C. (2011) In-Stream Large Wood Mobility and Recruitment in Two Channels in the Coastal Mountain Range, Chile. Bosque, 32, 247-254. http://dx.doi.org/10.4067/S0717-92002011000300006

[11] Ulloa, H., Iroumé, A.,Lenzi, M.A., Andreoli, A., Álvarez, C. and Barrera, V. (2011) Large Wood in Two Catchments from the Coastal Mountain Range with Different Land Use History. Bosque, 32, 235-245. http://dx.doi.org/10.4067/S0717-92002011000300005

[12] Mao, L., Andreoli, A., Iroumé, A., Comiti, F. and Lenzi. M.A. (2013) Dynamics and Management Alternatives of In-Channel Large Wood in Mountain Basins of the Southern Andes. Bosque, 34, 319-330. http://dx.doi.org/10.4067/S0717-92002013000300008

[13] Rigon, E., Comiti, F. and Lenzi, M.A. (2012) Large Wood Storage in Streams of the Eastern Italian Alps and the Relevance of Hillslope Processes. Water Resources Research, 48, 1-18. http://dx.doi.org/10.1029/2010WR009854

[14] Lienkaemper, G.W. and Swanson, F.J. (1987) Dynamics of Large Woody Debris in Old-Growth Douglas-Fir Forests. Canadian Journal of Forest Research, 17, 150-156. http://dx.doi.org/10.1139/x87-027

[15] Abbe, T.B., Montgomery, D.R., Featherston, K. and McClure, E. (1993) A Process-Based Classification of Woody Debris in a Fluvial Network; Preliminary Analysis of the Queets River, Washington. EOS Transaction of the American Geophysical Union, 74, 296.

[16] Mazzorana, B. (2009) Woody Debris Recruitment Prediction Methods and Transport Analysis. Ph.D. Thesis, Institute of Mountain Risk Engineering, University of Natural Resources and Applied Life Sciences, Vienna.

[17] Abbe, T.B. and Montgomery, D.R. (1996) Large Woody Debris Jams, Channel Hydraulics and Habitat Formation in Large Rivers. Regulated Rivers: Research and Management, 12, 201-221. http://dx.doi.org/10.1002/(SICI)1099-1646(199603)12:2/3<201::AID-RRR390>3.0.CO;2-A

[18] Cadol, D., Wohl, E., Goode, J.R. and Jaeger, K.L. (2009) Wood Distribution in Neotropical Forested Headwater Streams of La Selva, Costa Rica. Earth Surface Processes and Landforms, 34, 1198-1215. http://dx.doi.org/10.1002/esp.1800

[19] Nakamura, F. and Swanson, F.J. (1994) Distribution of Coarse Woody Debris in a Mountain Stream, Western Cascades Range, Oregon. Canadian Journal of Forest Research, 24, 2395-2403. http://dx.doi.org/10.1139/x94-309

[20] Baillie, B.R., Cummins, L. and Kimberley, M.O. (1999) Measuring Woody Debris in the Small Streams of New Zealand's Pine Plantations. New Zealand Journal of Marine and Freshwater Resources, 33, 87-97. http://dx.doi.org/10.1080/00288330.1999.9516859

[21] Herrero, C., Krankina, O., Monleon, V.J. and Bravo, F. (2014) Amount and Distribution of Coarse Woody Debris in Pine Ecosystems of North-Western Spain, Russia and the United States. iForest, 7, 53-60.

[22] Gurnell, A.M. (2003) Wood Storage and Mobility. In: Gregory, S.V., Boyer, K.L. and Gurnell, A.M., Eds., The Ecology and Management of Wood in World Rivers, American Fisheries Society Symposium 37, Bethesda, 75-91.

[23] Seo, J. I. and Nakamura, F. (2009) Scale-Dependent Controls upon the Fluvial Export of Large Wood from River Catchments. Earth Surface Processes and Landforms, 34, 786-800. http://dx.doi.org/10.1002/esp.1765

[24] Wohl, E.E. and Jaeger, K.L. (2009) A Conceptual Model for the Longitudinal Distribution of Wood in Mountain Streams. Earth Surface Processes and Landforms, 34, 329-344. http://dx.doi.org/10.1002/esp.1722 